\title{
DIVERSION OF FISHING PRESSURE ON THE ECONOMICALLY IMPORTANT SPECIES BARBUS BARBUS (LINNAEUS, 1758) TO PROTECT THE COMMUNITY INTEREST CONGENERIC BARBUS MERIDIONALIS RISSO 1826, BASED ON A DECISION-SUPPORT MANAGEMENT SYSTEM
}

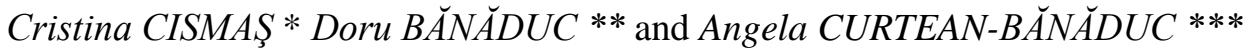

* "Lucian Blaga" University of Sibiu, Faculty of Sciences, Department of Informatics, Dr. Ion Raţiu Street 5-7, Sibiu, Sibiu County, Romania, RO-550012, cristha_83@yahoo.com, cristina.cismas@ulbsibiu.ro ** "Lucian Blaga" University of Sibiu, Faculty of Sciences, Applied Ecology Research Centre, Dr. Ion Raţiu Street 5-7, Sibiu, Sibiu County, Romania, RO-550012, ad.banaduc@yahoo.com, doru.banaduc@ulbsibiu.ro *** “Lucian Blaga” University of Sibiu, Faculty of Sciences, Department of Ecology and Environmental Protection, Dr. Ion Raţiu Street 5-7, Sibiu, Sibiu County, Romania, RO-550012, angela.banaduc@ulbsibiu.ro

KEYWORDS: fish species habitat necessities, pressures, threats, on site adapted management elements, Târnava River basin, Transylvania, Romania.

ABSTRACT: Diversion of fishing pressure on the economically important species Barbus barbus (Linnaeus, 1758) to protect the Community interest congeneric Barbus meridionalis Risso 1826, based on a decision-support management system.

The ADONIS:CE instrument has been used in the field of congeners species, Barbus barbus - of economic interest and Barbus meridionalis - of conservation interest, to build a support-system model for management decision-making. Analysis of the habitat needs and the indicators for favorable conservation status have identified pressures and threats to these fish species for which management actions have been proposed. This management system favors the decrease of fishing pressure on Barbus meridionalis species by its transfer to Barbus barbus species.

ZUSAMMENFASSUNG: Das Umlenken des Drucks fischereilicher Nutzung auf die wirtschaftlich wichtige Art Barbus barbus (Linnaeus, 1758) im Hinblick auf den Schutz von Barbus meridionalis Risso 1826, einer verwandten Art von Gemeinschaftlichem Interesse aufgrund eines Unterstützungsystems für Management-Entscheidungen.

Das ADONIS:CE Unterstüzungssystem wurde als Grundlage eines Modells für Managmententscheidungen betreffend die beiden verwandten Arten Barbus barbus von wirtschaftlichem und Barbus meridionalis von naturschutzfachlichem Interesse eingesetzt. Dabei wurden Habitatansprüche und Indikatoren des günstigen Erhaltungszustandes analysiert, Nutzungsdruck und Bedrohungen auf diese beiden Arten festgestellt sowie ein entsprechendes Managment vorgeschlagen. Dieses System begünstigt die Verminderung des Drucks durch fischereiliche Nutzung auf Barbus meridionalis, der auf Barbus barbus übertragen wird.

REZUMAT: Devierea presiunii pescuitului asupra speciei importante economic Barbus barbus (Linnaeus, 1758) în vederea protejării speciei congenere de interes comunitar Barbus meridionalis Risso 1826, pe baza unui sistem-suport de luare a deciziilor de management.

Instrumentul ADONIS:CE a fost utilizat în domeniul protecţiei speciilor congenere, Barbus barbus - de interes economic şi Barbus meridionalis - de interes conservativ, pentru construirea unui model de sistem-suport pentru luarea deciziilor de management. Au fost analizate necesităţile de habitat, indicatorii care relevă statutul de conservare favorabil, au fost identificate presiunile și ameninţările asupra acestor specii de pești și au fost propuse acţiuni de management. Acest sistem de management favorizează scăderea presiunii pescuitului asupra speciei Barbus meridionalis prin transferul acestuia asupra speciei Barbus barbus. 


\section{INTRODUCTION}

To guarantee the species of Community interest surviving, the European Union countries assent on the Habitats Directive in 1992, in compliance with the fact that they should succeed in conservation of the targeted species and habitats included in this Directive (Annex 2), to maintain or increase their status (*, 1992).

In Romania, like in other European Union countries, the Natura 2000 protected sites were selected for conservation interests including for fish conservation. They were chosen for their suitability for the valuable species' conservation importance. Related to fish species of Community interest, the chosen European Natura 2000 network sites were realized based on some specific criteria like: well preserved fish populations, advantageous geographical positions, characteristic habitats, and last but not least not significant human impact presence.

Among the main elements based on which the Natura 2000 network can improve the European Union states' nature conservation are the institution capacity competence progress; improving the citizens' guidance and understanding, innovative and functional management for species and habitats of conservation concern. (Bănăduc, 2007, 2008, 2010, 2011; Papp and Toth, 2007; Curtean-Bănăduc and Bănăduc, 2008; Bănăduc et al., 2012)

Among numerous human impacts on fish, overfishing takes place when more fish are taken than one or many populations can naturally resupply, they becoming ecologically and/or economically unsustainable, is one of the main causes which induce different fish species disappearance or populations decreasing (Clover, 2004; Allan et al., 2005; Bănăduc, 2016).

The need or greed for fish protein is obvious all over the world, and this type of pressure requires a concentrated innovative effort in finding solutions with both conservative and economic reasons (Pontecorvo, 2007; Agnew et al., 2009; Monte-Luna, 2016).

This paper goal proposes not the already classic poor way of thinking and acting of only banning fishing of certain fish species of conservative interest, but offering through an alternative type of basin fish resources use management, making fishing activities sustainable without jeopardizing the protected species (Sissenwine et al., 2014).

The Carpahians basin are under constant pressure due to overfishing, including poaching (Curtean-Bănăduc et al., 2007; Florea, 2011; Pekárik et al., 2011; Guti, 2014; Didenko et al, 2014) and the Târnava Basin is not an exception in this respect (CurteanBănăduc and Bănăduc, 2007) a basin where live many protected fish species, Barbus meridionalis Risso 1826 being one of them. This species is terra typical to the Mureș River in which Târnava River is flowing, in the studied lotic sectors it is living sometimes together with its congener species Barbus barbus (Bănărescu, 1964; Bănărescu and Bănăduc, 2007).

In Târnava Basin fish fauna structure context applied management tools have to adapt new innovative management elements, basically the present legal and illegal fishing pressure on Barbus meridionalis protected species it is suggested to be diverted on its congeneric species Barbus barbus, which has a higher economic value and no conservation value.

In nature protection, modelling is usually used to obtain the "big picture" of different systems and/or actions of specific domains. The components of the modelling process are useful in discerning the distinct stages of adaptive species and their habitat management. Utilizing the ADONIS:CE software product, can design models that support management tasks. Such models focus on three operational areas, valuable for environment protection: 1) to ascertain the present state, 2) to evaluate the outcomes of adjustments and 3) to propose a program to improve the present state in a wanted way. Finally, diverse diagrams can be created to reveal management aspects. (Hall and Harmon, 2005) 


\section{MATERIAL AND METHODS}

The studied area, the Târnava River basin (Fig. 1) is placed in the inner part of the Romanian Carpathians arch, runs off the Transylvania Depression, in particular its southern part the Târnavelor Plateau. With a basin area of $6,157 \mathrm{~km}^{2}$, a length of $249 \mathrm{~km}$ and a falling elevation of around 1,250 m, Târnava River is one of the principal tributaries of the Mureş River, representing 21\% of its basin. It is formed at the confluence of Târnava Mare River (3,606 km² basin surface; $221 \mathrm{~km}$ length) and Târnava Mică River $\left(2,049 \mathrm{~km}^{2}\right.$ basin surface and $191 \mathrm{~km}$ length) near the city of Blaj. (Tufescu, 1966; Roşu, 1980; Posea et al., 1982)

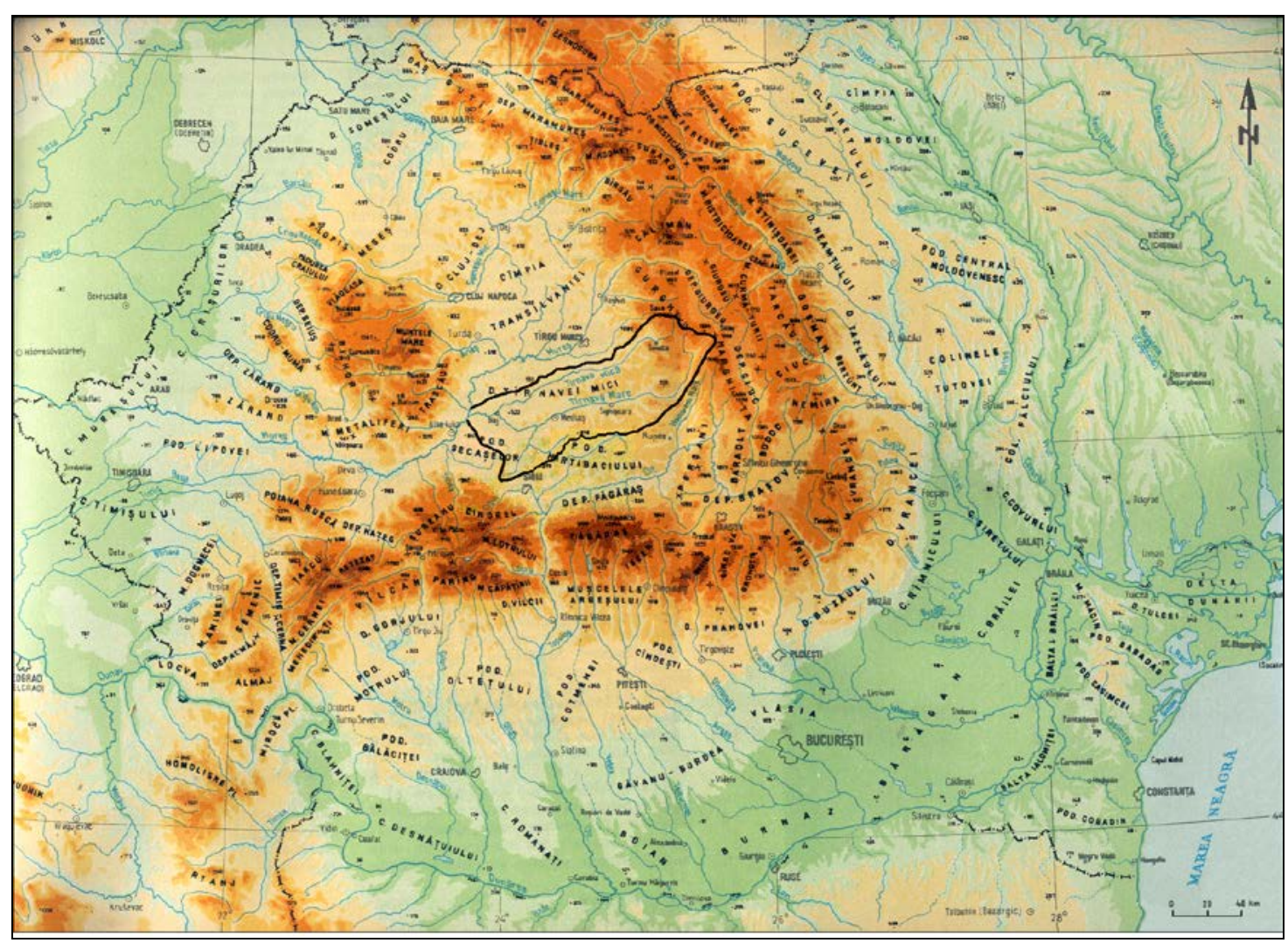

Figure 1: The Târnava River basin study unit location (Badea et al., 1983 - modified).

The Barbus barbus species (Fig. 2) individuals were sampled in almost all the middle and lower sectors of Târnava Mare, Târnava Mică and Târnava rivers in 2016, using electrofishing, these individuals were freed after a fast in situ identification in their natural habitat. In addition, reference data for Barbus barbus and Barbus meridionalis species (Fig. 3) presence and status was based on a similar approach study of Bănăduc et al. (2015), and on the legal and illegal fishers captures.

The researched studied habitat typical features of the fish populations were assessed based on particular criteria including: population size, size of range, the balanced allocation of fish in age classes, and high/low number of individual fish species in fish assemblages.

The habitat needs, pressures, and threats on Barbus barbus were researched in relation with their ecological status, the correlations between them and the conservation circumstance of this species. 


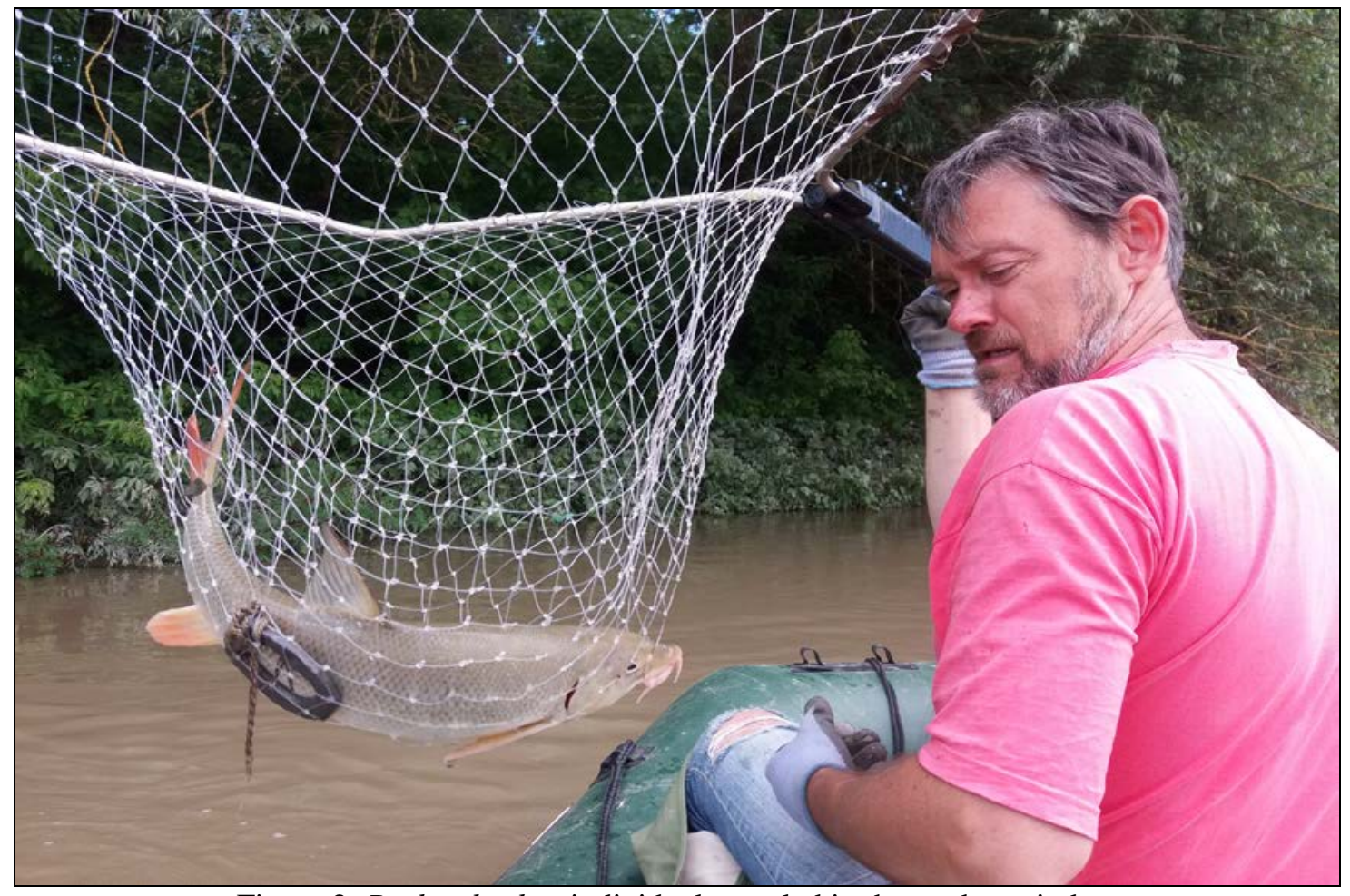

Figure 2: Barbus barbus individual sampled in the study period.

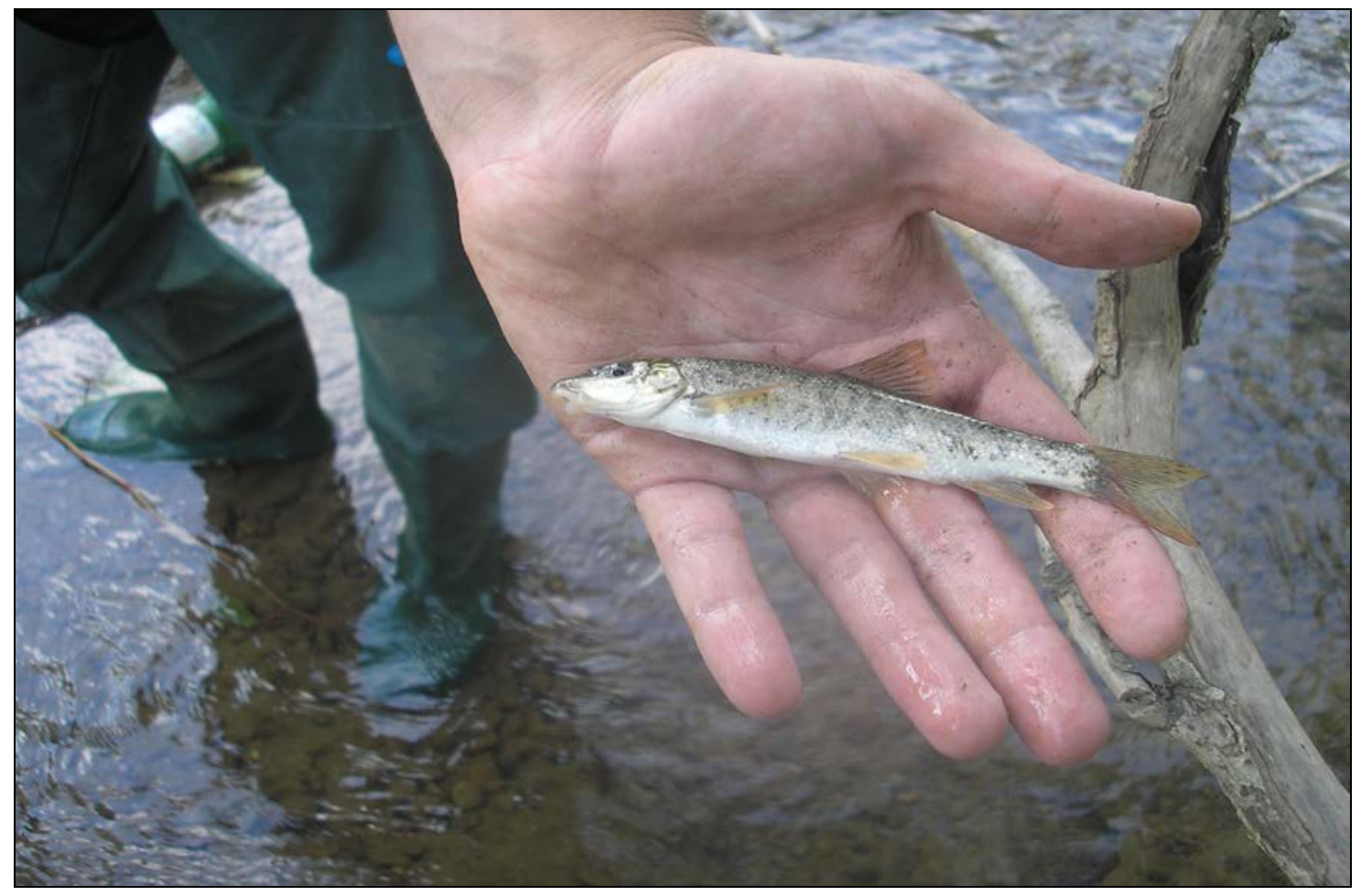

Figure 3: Barbus meridionalis - juvenile - individual fished by poachers in the study period. 
A flexible management model was proposed to set up a fitting management plan that would surely protect the studied congeneric fish species that are present in the studied lotic ecosystems, with an emphasis on necessary processes. The ADONIS:Community Edition (ADONIS:CE) software, invented by the Business Object Consulting (BOC) Group, was used here. This free software is an accessible form of ADONIS with some limitations (compared with the commercial version). It uses a Business Process Model and Notation (BPMN), a standardized modelling language that supports highlighting recognizable processes. ADONIS:CE is normally used as an access point to Business Process Management. These processes can be modelled using compatible notation. $(* *)$

\section{RESULTS AND DISCUSSION}

\section{Identified human pressures and threats}

This research outcomes highlight the fact that the principal pressures and threats on Barbus barbus species are: destroying/changing characteristic habitats, water pollution, overfishing and poaching, the lotic continuum fragmentation due to hydrotechnical works, riparian vegetation destruction, deforestation of riverine basins.

\section{Identified specific requirements}

Both the adults and juveniles need a significant/close to natural water flow and relatively high depths of the water (minimum one m), with rocky/sandy substrata, and moderate speed of the water flow.

\section{Proposed specific habitat indicators}

In the studied lotic ecosystems, main habitat indicators are proposed as explanation for the presence/absence and relative abundance of Barbus barbus: average water flowing surface speed (proportion $66 \%$ of the river), combined with sandy substratum (33\% of the river), and/or mixed with rocky substrata (66\% of the river), and water surface with relatively high depth of the water (66\% of the river).

\section{Management measures}

Management features have been a purpose for analztical studies, also a demand for administrators which face various management pressures and threats. As a repercussion there are numerus point of views and models which oscilate based on source, system and elaboration complexity. The management indicators can be approached within a process formed of six steps (Krause and Mertins, 1999): developing a process value chain model, identify the key success factors, defining the performance indicators, collection and verification of the data, evaluation of the performance indicators, and implementing a continuous process.

This path based on a model it is supported by the learning process which occur while preparing the process maps; and it establishes the need for management elements assembled around the record sheets of management measures. Therefore it is important to stress that building on the necessity to find an indicator set for evaluation an entity's overall achievement, the suggested model find the principal value delivery process, to which an indicator set for process evaluation can be designate, which are inducing by diagnosing the success factors, for the process and for the entity's global performance (Miricescu, 2011, 2014). 
Accordingly with this model we suggest that the principal management measures be: preservation of the natural morphology of the lotic systems and their banks; the riverbed mineral exploitation should be done only outside the lotic habitats characterised by average flow speed, rocky substratum and relatively deep water depth; preserving the vegetation of the basin as close to the natural status for sediments control in the basin; preserving the riverine culloars of vegetation with a length of minimum 100-200 m on both banks of rivers for their role of sediment traps; a ban on the disposing of any type of waste in streams and rivers; keeping a permanent high/medium level of the water on rivers and streams especially in drought periods based on avoiding of significant water extractions; diminishing water pollution; and last but not least the creation of a monitoring system for ichthyofauna.

\section{Adjusted model for the site management}

In this paper, we tried to make an overview of the ecological requirements for Barbus barbus in the Târnava Mare Basin. ADONIS:CE software has been used for this purpose, which is a tool for business process modeling and which offers different formats to export modeled data (the one chosen by us is jpg - for a good view of processes) and supports any number of levels of decomposition (subprocess). The following modeling objects were used: start (yellow triangle - beginning of the process), activities (blue rectangles - shows the ecological requirements and management measures recommended for conservation of the Barbus barbus species); decisions (yellow diamonds - which check whether the indicator of critical requirements towards the selected habitat meets or not the favorable conservation status); the decisions are accompanied by variables (green circle - name of the indicator) and generators (which define the probability that the selected indicator falls within the limits of the favorable conservation status) according to the data collected from the field; subprocess (blue triangle - a sequence of activities, decisions, that acts as processes and can be called in the main process); end (yellow circle - end of process).

\section{Model description}

The modeling of the Barbus barbus was carried out using a basic process and three subprocesses presenting the management measures for this fish species to be in favorable conservation status (Fig. 4 - process hierarchy).

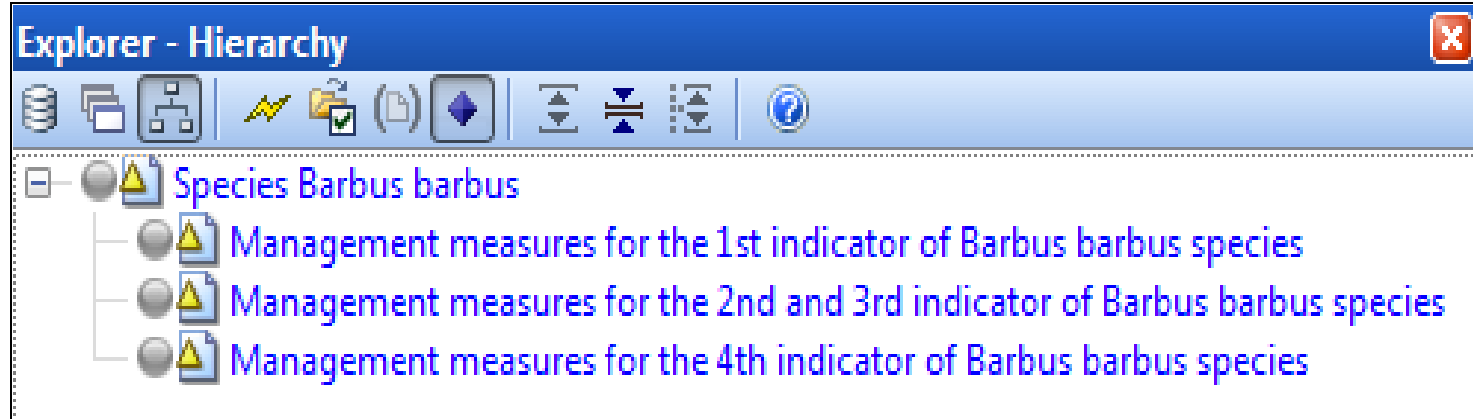

Figure 4: Barbus barbus - process hierarchy. 
Interpretation of the process modelling (Fig. 5 - the main process for Barbus barbus):

- this process begins with two activities describing the specific requirements for habitats (the species needs for breeding, shelter, trophic resources) and field observations;

- follows four decisions (for the four possible indicators studied: average water flowing surface speed, sandy substratum, gravel substratum, water surface with relatively high depth of the water) showing the value of the favorable conservation status of the analyzed indicator - of the habitat critical requirements - that are correlated with the actual value of the indicator (the one measured on the ground);

- each decision has associated a variable (indicator name) and a random generator in which it is determined the probability that the indicator is in favorable conservation status;

- if the water with moderate flow state is between 66-100\%, ("Moderate_flow_of_water" = "Yes", probability: 66\%) then the process continues with the next indicator;

- if the current state of the moderately flowing water surface does not fulfill $66-100 \%$, (branch "Moderate_flow_of_water" = "No", probability: 34\%) then the process continues with the subprocess Management measures of the first indicator of Barbus barbus (Fig. 6);

0 this subprocess contains the activities to be performed - management measures - so that the selected indicator meets the favorable conservation status;

o a loop is formed and returns to the decision of the first indicator, repeating the management measures until is fulfill the favorable conservation status;

- if all the indicators meet the conditions presented (the "Yes" branch of each: "Moderate flow_of_water" = "Yes", probability: 66\%; "Sandy_substrate" = "Yes", probability: 33\%; "Gravel_substrate" = "Yes”, probability: 66\%; "Water_large_depth" = "Yes”, probability: $66 \%$ ) then "Implementation of an integrated seasonal monitoring system" is recommended and the process continues with the decision "if the conservation status is favorable";

o if this is done (branch "Conservation_state" = "Yes", probability: 30\%), there are a number of activities that present other characteristics of the Barbus barbus species (other ecological requirements, which is the breeding period, which is the distribution in the protected area as well as the pressures and threats of the species) after which the process ends;

0 if the decision that verifies the favorable conservation status is not fulfilled (branch "Conservation_state" = "No", probability: 70\%), the process returns to the second activity (Field observations) and will resume verification of possible indicators;

- if you go through the basic model until you reach the third indicator (decision: The current state of gravel substratum weight is more than 66\%) and goes to the "Yes" branch ("Gravel_substrate" = "Yes", probability: 66\%), then the model continues with the fourth indicator ("The state of water surface area with relatively large depth is more than $66 \%$ ");

- if the decision regarding the third indicator is not fulfilled (the "No" branch, "Gravel_substrate" = "No", probability: 34\%), the subprocess "Management measures for the second and third indicator of Barbus barbus species" (Fig. 7) and the activity of ensuring a permanent water regime are used;

- if the last indicator is fulfill (branch "Water_large_depth" = "Yes", probability: 66\%), then the process continues with the implementation of an integrated monitoring system;

- if the last indicator is not fulfilled (branch "Water_large_depth" = "No", probability: 33\%), then the subprocess Management measures for the fourth indicator is used (Fig. 8).

The management measures for the four indicators are in fact activities that should be carried out for the preservation and conservation of the Barbus barbus species and implicitly for the assurance its good use from an economic point of view. 


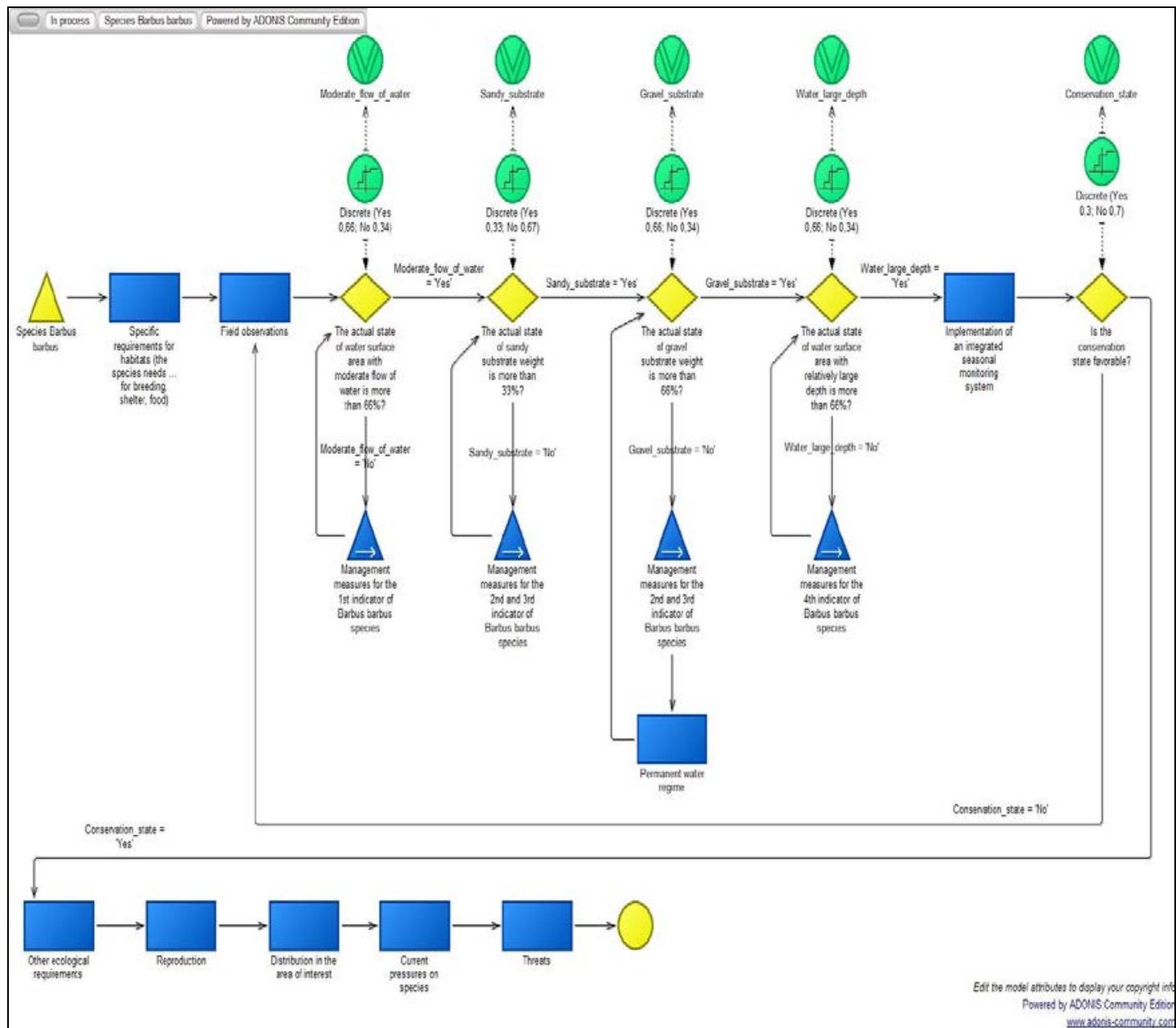

Figure 5: Barbus barbus - the main process.

These management measures could not be modeled by one subprocess, because even if some of them are repeated, they are still thought about the importance of each indicator.

The management measures for the first indicator of Barbus barbus species (Fig. 6) are structured in four activities: maintaining the natural morphodynamics of the riverbeds (it is recommended to prohibit the constructions which have the effect of changing the flow rate regime and the composition of the bed substratum - for example, the construction of bridges, floors, etc., should be carried out at the level of multi-annual maximum flows, so as not to cause significant disturbance of the water drainage regime); the exploitation of aggregates in the riverbed should not be allowed (prohibition of the exploitation of aggregates in medium speed-flowing areas, rocky substrates and relatively deep depth, and less than five km between operations in large and medium rivers, with no self-regeneration capacity of each exploited sector); prohibition of the abandonment of waste (in wetlands adjacent to watercourses too); permanent water regime (on small river sectors, in particular, a permanent water regime, e.g. a reduction in flow take-offs during periods of drought, must be ensured; the effects of anthropogenic impacts such as organic and chemical pollution must be diminished). 


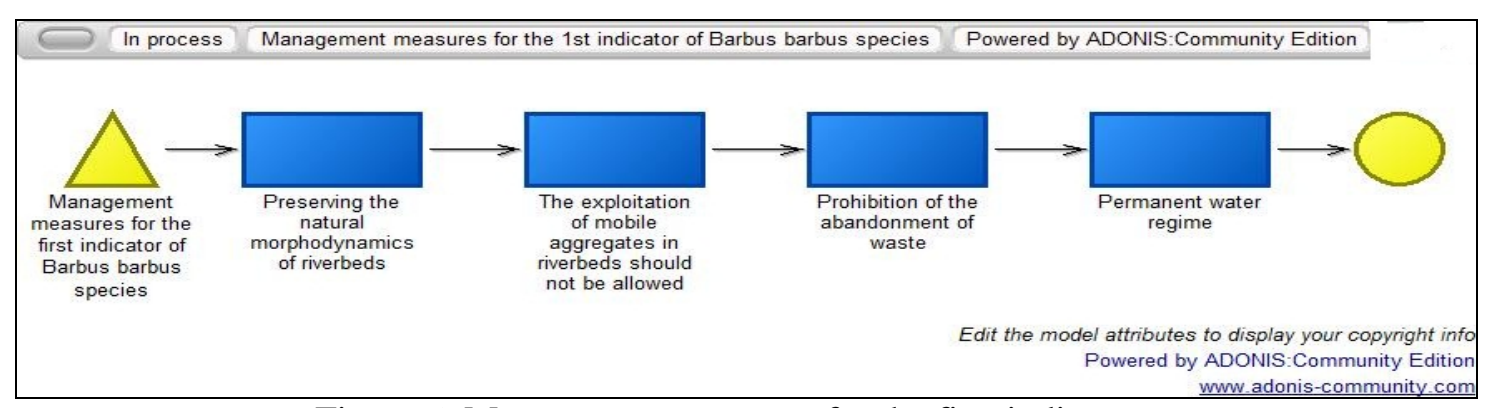

Figure 6: Management measures for the first indicator (average water flowing surface speed) of Barbus barbus species.

The management measures for the second and third indicators (sandy substrate and gravel substrate) of Barbus barbus species (Fig. 7) are as follows: maintaining the natural morphodynamics of the riverbeds; the exploitation of mobile aggregates in the riverbed should not be allowed; conservation of vegetation (in the pools of interest as close as possible to the natural state in order to control erosion and sediment transport); preservation of natural vegetation corridors; prohibition of the abandonment of waste (of any nature in the wetland and wetlands adjacent to watercourses).

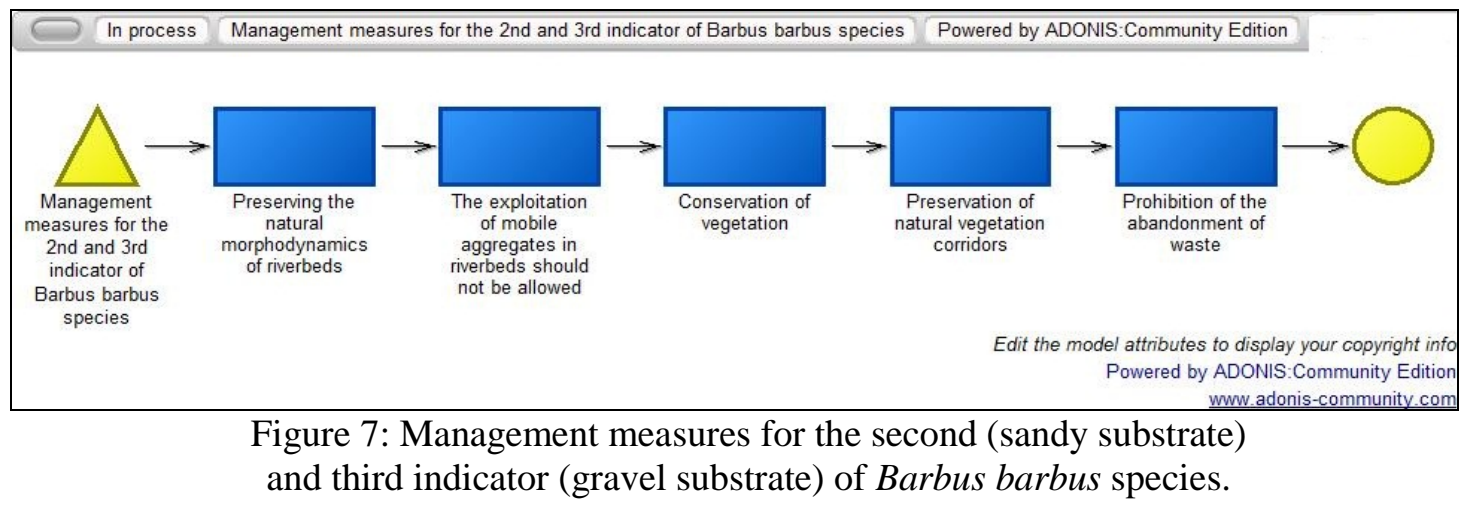

The management measures for the fourth indicator (water surface with relatively depth of the water) of Barbus barbus species (Fig. 8) are: maintaining the natural morphodynamics of the riverbeds; conservation of vegetation (in the pools of interest as close as possible to the natural state in order to control erosion and sediment transport); preservation of natural vegetation corridors; prohibition of the abandonment of waste (of any nature in the wetland and wetlands adjacent to watercourses); permanent water regime.

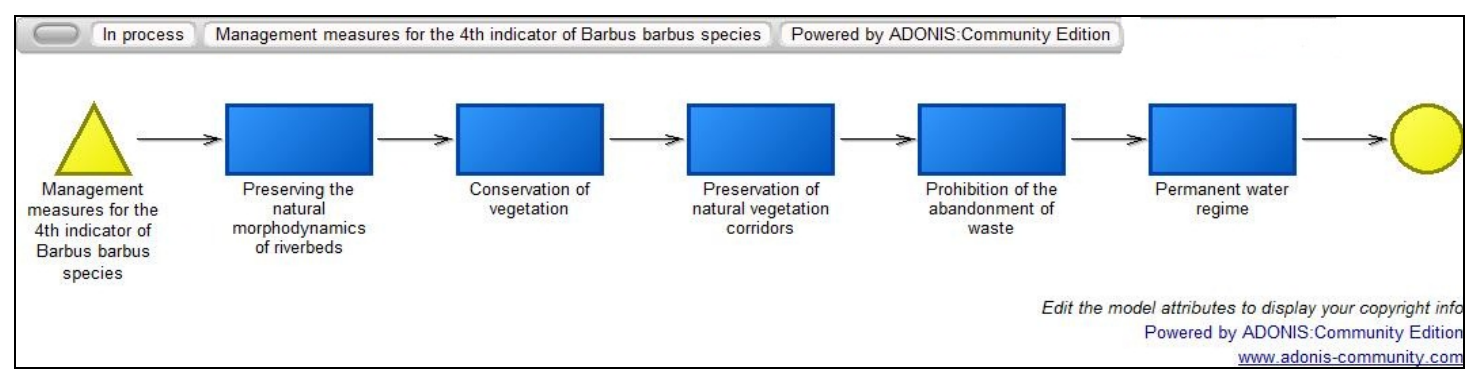

Figure 8: Management measures for the fourth indicator (surface with relatively deep water). 
For the Barbus meridionalis species conservation in Târnava River basin, the following lotic sectors should have a minimum of six months per year (February-Jully) total fishing banning period, in the lotic sectors of Târnava Mică River (between the localities Praid and Târnăveni/between the sampling stations Tm3-Tm7) and for Târnava Mare River (between Zetea to Mediaş; TM5-TM9) (Fig. 9) where Barbus meridionalis can have a high abundance, and a good ecological status.

In such a way the fishing pressure on the protected fish species Barbus meridionalis can be diverted on the much more economically valuable and not protected species Barbus barbus in the downstream lotic sectors Târnăveni to Blaj localities (in Târnava Mică River) and from Mediaş to Blaj localities (in Târnava Mare River) (Fig. 9) where Barbus barbus can have a high abundance and a good ecological status. The Târnava River, after the Târnava Mare and Târnava Mică rivers confluence, is in the same downstream category.

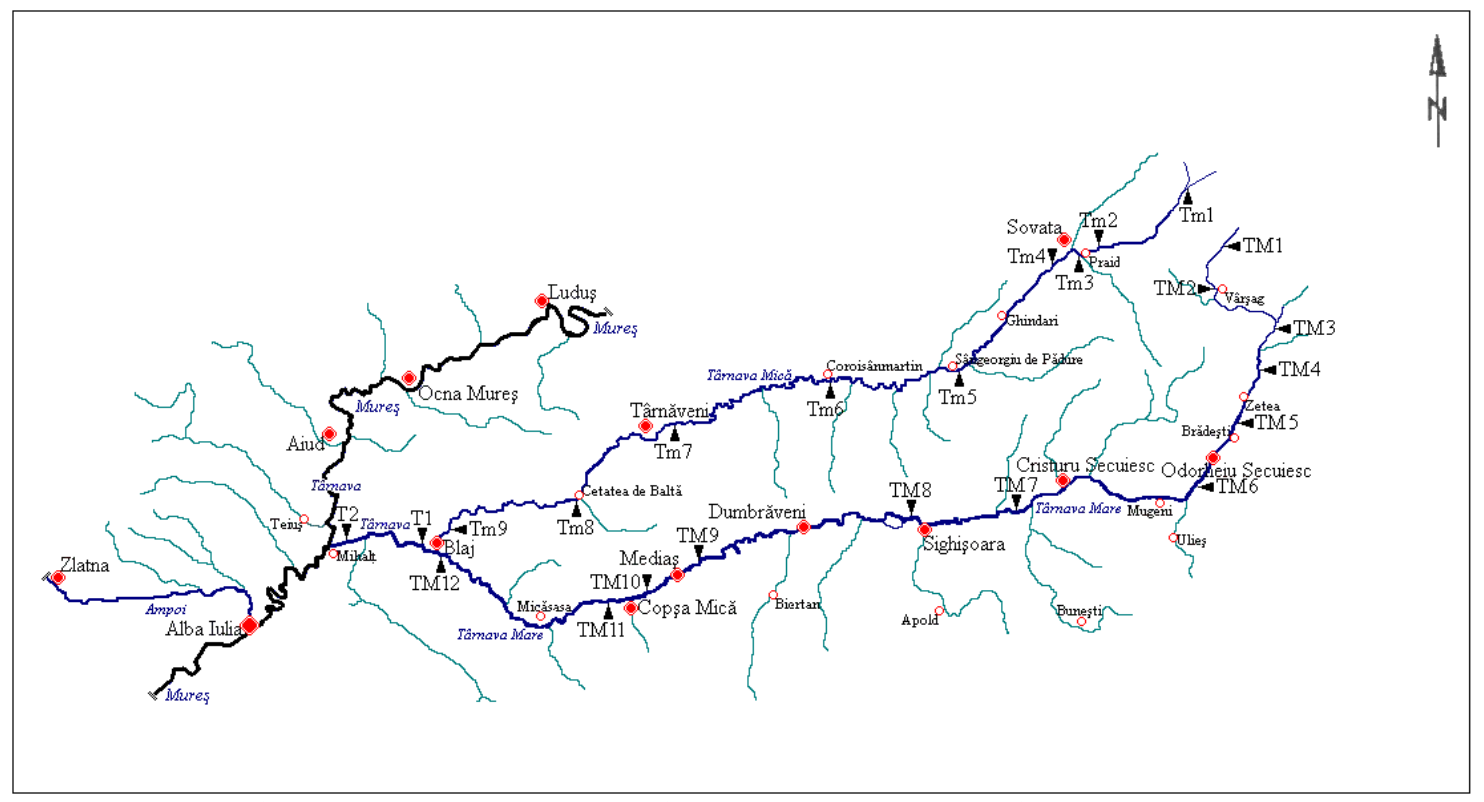

Figure 9: The researched stations on Târnava Mare River ( TM), Târnava Mică River $(-\mathrm{Tm})$ and Târnava River $(-\mathrm{T})$.

\section{CONCLUSIONS}

In the conditions in which poaching and overfishing is a common phenomenon all over the year in the Târnava River basin, the maintaining of the attention and interest of the (legal and illegal) fishermen on the lower sectors of Târnava Mare and Târnava Mică, and Târnava River, to divert their pressure and threat from the upper lotic sectors with Barbus meridionalis, to the lower sectors with higher Barbus barbus abundance habitats should to be properly managed as it was suggested here, in the context of this paper proposed decisionsupport management system.

The main inventoried pressures and threats to the fish species Barbus barbus in Târnava River basin were: destroying/changing characteristic habitats, water pollution, overfishing and poaching, the lotic continuum fragmentation due to hydrotechnical works, riparian vegetation destruction, deforestation of riverine basins. 
Very important for direct Barbus barbus and indirect Barbus meridionalis species protection are: the natural riverbed morphodynamics protection, the decreasing of the present lotic fragmentation, the prevention of riverbed overexploitation, the riverine vegetation protection, the ecological rehabilitation of the natural morphodynamic of riverbeds, efficient poaching control, integrated waste management, diminishing organic and chemical water pollution, and the implementation of a seasonal permanent monitoring system for fish fauna.

In this specific study, a basic model for management decisions in order to support the Barbus barbus fish species was designed and can be implemented in the field.

The ADONIS:CE was used in fish conservation area of interest, proposing a management model for Barbus barbus species that include its major needs concerning the habitat, the indicators that draw out a good ecological status - the proper management to avoid and/or eliminate the pressures and threats which negatively affect this species populations, the local populations age classes long term conservation.

This specific on-site, on habitats and on species management decisions sustaining model plan for Barbus barbus, should be included in an integrated management model for the Târnava River fish communities, with this aim similar management decisions sustaining models for other fish species of economic-conservation interest should be designed.

\section{ACKNOWLEDGEMENTS}

The authors wish to thank to Mr. Professor Emil M. Popa for his valuable support in informatics, and to the numerous fishers operating in the Târnava River basin for their cooperation during the study. This research information was acquired in the study period for POS Mediu, priority ax 4 project code SMIS - CSNR 17049 "Pentru Comunităţi Locale și Natură - Bazele managementului integrat Natura 2000 în zona Hârtibaciu - Târnava Mare Olt (PH+ PRO MANAGEMENT Natura 2000)" and for Project ID 66243, SIDPOP "Instrument suport pentru luarea deciziilor în domeniul managementului poluanţilor organici persistenţi. Studiu de caz: Bazinul hidrografic Mureş", finanţat în cadrul programului R004 „Reducerea substanţelor periculoase, prin Mecanismul Financiar al Spaţiului Economic European (SEE). 


\section{REFERENCES}

1. Allan J. D., Abell R., Hogan Z., Revenga C., Taylor B. W., Welcome R. L. and Winemiller K., 2005 - Overfishing of inland waters, BIOScience, 55, 12, 1041-1051.

2. Agnew D. J., Pearce G., Peatman T., Watson R., Beddington J. R. and Pitcher T., 2009 Estimating the Worldwide Extent of Illegal Fishing, PLoS ONE, 4, e4570.

3. Clover C. 2004 - End of the line: How overfishing is changing the world and what we eat, Ebury Press, London ISBN 0-09-đ189780-7.

4. Curtean-Bănăduc A. and Bănăduc D., 2007 - Benthic macroinvertebrates and fish communities of some southern Târnava Mare River tributaries (Transylvania, Romania), Transylvanian Review of Systematical and Ecological Research, 4, 135-148.

5. Curtean-Bănăduc A., Bănăduc D. and Bucşa C., 2007 - Watersheds Management (Transylvania, Romania) - implications, risks, solutions, Strategies to enhance environmental Security in transition countries, NATO Science for Peace and Security Series C-Environmental Security, Springer, 225-238, DOI: 10.1007/978-1-4020-5996-4_17, ISSN 1971-4668, ISBN 978-1-4020-5994-0.

6. Didenko A. V., Velykopolsky I. I. and Buzevich I. Y., 2011 - Illegal fishing in the Tisza River drainage within Ukraine: a threat for local fish stocks? Archives of Polish Fisheries, 19, 249-257.

7. Florea L., 2011 - The characteristics of Freshwater Fish Population in the Danube River near Brăila within the period 2006-2008, Journal of Environmental Protection and Ecology, ISSN 1311-5065, 12/3, 814-824814.pdf

8. Guti G., 2014 - Can anadromous sturgeon populations be restored in the middle Danube River, Acta Zoologica Bulgarica, Supplement 7, 63-67.

9. Hall C. and Harmon P., 2005 - The Enterprise Architecture, Process Modeling and Simulation Tools Report, Version 1.1 (2005) November.

10. Pekárik L., Švátora M., Černy J. and Koščo J., 2011 - Longitudinal structure of fish assemblages in a minimally disrupted stream, Biologia, 66, 5, 886-892.

11. Monte-Luna P., Lluch-Belda D., Arreguin-Sánchez F., Lluch-Cota S. and Villalobos-Ortiz H., 2016 - Approaching the potential of world marine fish, Transylvanian Review of Systematical and Ecological Research, 18.1, 45-56.

12. Sissenwine M. M., Mace P. M. and Lassen H. J., 2014 - Preventing overfishing: evolving approaches and emerging challenges - ICES, Journal of Marine Science, 71, 153-156.

13. Bănăduc D., Cismaş I.-C. and Curtean-Bănăduc A., 2015 - Barbus meridionalis Risso 1826 on site decisions support management system - a Transylvanian Natura 2000 Site study case, Acta Oecologica Carpatica, VIII, Edit. Universităţii "Lucian Blaga", Sibiu, 173-188.

14. Tufescu V., 1966 - Subcarpaţii şi depresiunile marginale ale Transilvaniei, Edit. Ştiinţifică, 1966, Bucureşti. (in Romanian)

15. Roşu A., 1980 - Geografia Fizică a României, Edit. Didactică şi Pedagogică, Bucureşti. (in Romanian)

16. Posea G. et al., 1983 - Enciclopedia Geografică a României, Edit. Ştiinţifică şi Enciclopedică, Bucureşti. (in Romanian)

17. Krause O. and Mertins K., 1999 - Performance management, in Mertins K., Krause O. and Schallock O., Global Production Management, Proceedings of the IFIP, WG5.7 International Conference on Advances in Production Management Systems, September, 243-251.

18. Miricescu D., 2011 - Study on temporal influences on management and managers of business organizations, Proceedings of RMEE, Todesco Publising House, 479-490.

19. Miricescu D., 2014 - Semnele şi amprenta timpului asupra managementului contemporan, Edit. Universităţii “Lucian Blaga” din Sibiu, Sibiu, 69-88. (in Romanian)

20. *, 1992 - http://ec.europa.eu/environment/water/water-framework/index_en.html

21. $* *$ - http://www.boc-group.com/products/adonis/bpmn-method/ 